\title{
Venture Capital, Entrepreneurship and Women in Business
}

\section{Ann Winblad (HWVP)}

\section{KEYWORDS: Entrepreneurship, Venture Capital,} Women.

For venture capitalist Ann Winblad, being one of the lone women in a world dominated by men and hearing "no" at three pivotal occasions in her life only made her more determined and resourceful. After being turned down by 133 potential investors who scoffed at the idea of a venture capital firm that invested in software, she nonetheless found a way to launch Hummer Winblad, today a wildly successful firm and one of the early entrants in a now-booming field of VCs focused on the software industry. In this presentation from an EIX webinar, Winblad talks about her own journey, the three critical "nos" that shaped her career trajectory, the challenges for startups competing for funding, and how a company can improve its chances of securing its first round of capital.

\section{Learn More}

Advice, Best Practices and Inspiration for Women Entrepreneurs(https://eiexchange.com/women)

Additional search terms: women, female founders, women business owners, opportunity, financing, getting money for my business, finding investors 